\title{
Decomposition analysis of soybean in Amravati division
}

\author{
P. S. PARDHI, D. H. ULEMALE AND S. M. SARAP
}

Received : 25.06.2016; Revised : 19.08.2016; Accepted : 06.09.2016

\begin{abstract}
In this study an attempt has been made to study the growth and instability of soybean crop in Amravati division. The study was based on secondary data on area, production and productivity of soybean crop collected from various government publications. The study revealed that compound growth rate for area and production of soybean was recorded very high during period I. The co-efficient of variation with regards to area and production $(37.59 \%$ and $22.23 \%)$ were lowest in Amravati district. However, Coppock's instability index with regards to area and productivity (13.01\% and $18.84 \%)$ were lowest in Amravati division as a whole. At overall period, the area effect was most stronger factor for increasing production of soybean in all the districts and division as a whole.
\end{abstract}

KEY WORDS : Compound growth rates, Co-efficient of variation, Instability, Production, Productivity

How to cite this paper : Pardhi, P.S., Ulemale, D.H. and Sarap, S.M. (2016). Decomposition analysis of soybean in Amravati division. Internat. J. Com. \& Bus. Manage, 9(2) : 163-168. DOI: 10.15740/HAS/IJCBM/9.2/163-168.

\section{MEMBERS OF THE RESEARCH FORUM}

Correspondence to:

D. H. ULEMALE, Department of Agriculture Economics and Statistics, Shri Shivaji Agriculture College, AMRAVATI (M.S.) INDIA

Authors' affiliations:

P.S. PARDHI AND S.M. SARAP, Department of Agriculture Economics and Statistics, Shri Shivaji Agriculture College, AMRAVATI (M.S.) INDIA 